\title{
Neurite outgrowth stimulatory effects of culinary-medicinal mushrooms and their toxicity assessment using differentiating Neuro-2a and embryonic fibroblast BALB/3T3
}

\author{
Chia-Wei Phan ${ }^{1,2}$, Pamela David ${ }^{1,3^{*}}$, Murali Naidu ${ }^{1,3}$, Kah-Hui Wong $^{1,3}$ and Vikineswary Sabaratnam ${ }^{1,2}$
}

\begin{abstract}
Background: Mushrooms are not only regarded as gourmet cuisine but also as therapeutic agent to promote cognition health. However, little toxicological information is available regarding their safety. Therefore, the aim of this study was to screen selected ethno-pharmacologically important mushrooms for stimulatory effects on neurite outgrowth and to test for any cytotoxicity.

Methods: The stimulatory effect of mushrooms on neurite outgrowth was assessed in differentiating mouse neuroblastoma (N2a) cells. Neurite length was measured using Image-Pro Insight processor system. Neuritogenesis activity was further validated by fluorescence immunocytochemical staining of neurofilaments. In vitro cytotoxicity was investigated by using mouse embryonic fibroblast (BALB/3T3) and N2a cells for any embryo- and neuro-toxic effects; respectively.
\end{abstract}

Results: Aqueous extracts of Ganoderma lucidum, Lignosus rhinocerotis, Pleurotus giganteus and Grifola frondosa; as well as an ethanol extract of Cordyceps militaris significantly $(\mathrm{p}<0.05)$ promoted the neurite outgrowth in N2a cells by $38.4 \pm 4.2 \%, 38.1 \pm 2.6 \%, 33.4 \pm 4.6 \%, 33.7 \pm 1.5 \%$, and $35.8 \pm 3.4 \%$; respectively. The $I C_{50}$ values obtained from tetrazolium (MTT), neutral red uptake (NRU) and lactate dehydrogenase (LDH) release assays showed no toxic effects following $24 \mathrm{~h}$ exposure of N2a and $3 \mathrm{~T} 3$ cells to mushroom extracts.

Conclusion: Our results indicate that G. lucidum, L. rhinocerotis, P. giganteus, G. frondosa and C. militaris may be developed as safe and healthy dietary supplements for brain and cognitive health.

Keywords: Culinary-medicinal mushrooms, Neurite outgrowth, Cytotoxicity, Mouse neuroblastoma N2a cell, Mouse 3T3 embryonic fibroblast, Neurofilament

\section{Background}

Neurite outgrowth is an important event in neuronal path finding and the establishment of synaptic connections during development [1,2]. It is also essential in neuronal plasticity, neuronal regeneration after injury $[3,4]$ and neurodegenerative conditions such as Alzheimer's and Parkinson's diseases [5]. Therefore, treatments aiming at

\footnotetext{
* Correspondence: rosiepamela@um.edu.my

'Mushroom Research Centre, Institute of Biological Sciences, Faculty of

Science, University of Malaya, 50603 Kuala Lumpur, Malaysia

${ }^{3}$ Department of Anatomy, Faculty of Medicine, University of Malaya, 50603

Kuala Lumpur, Malaysia

Full list of author information is available at the end of the article
}

promoting neurite outgrowth and preserving the neurite network and synaptic connections are needed.

The potential use of culinary-medicinal mushrooms in neurodegenerative diseases is being explored [6]. On-going research in our laboratory shows that Hericium erinaceus (Bull.: Fr) Pers. (monkey's head mushroom, lion's mane mushroom and Yamabushitake) [7], Lignosus rhinocerotis (Cooke) Ryvarden (tiger milk mushroom) [8,9], and Pleurotus giganteus (Berk.) Karunarathna \& K.D. Hyde (morning glory mushroom, cow's stomach mushroom) [10] exhibit neurite outgrowth stimulatory effects in NG108-15 and PC12 cell lines. This observation raised a question with respect to the neurodevelopmental effects, 
if any, of culinary-medicinal mushrooms. Birth defects have been identified as a growing social and healthcare issue. Congenital diseases are present in $2-3 \%$ of human newborns [11]. About $20 \%$ of the birth defects are due to genetic anomaly and $10 \%$ are caused by environmental factors during pregnancy [12]. Therefore, toxicological safety assessments of food, chemicals and drugs to evaluate the effects on reproductive health and for embryotoxicity have become an important requirement. Thus, the aims of the present study were (a) to evaluate neurite outgrowth stimulatory effects of selected culinary-medicinal mushrooms using neuroblastoma-2a (N2a) cells and (b) to assess the neuro- and embryotoxicity of the mushroom extracts using N2a and 3T3 fibroblasts. The results will enable us to select potential mushrooms for further in depth in vivo developmental toxicity evaluation.

\section{Methods}

\section{Mushroom and plant samples}

The mushrooms were authenticated by experts in the Mushroom Research Centre, University of Malaya and voucher specimens were deposited in the University of Malaya herbarium at Rimba Ilmu (Table 1). Fresh fruiting bodies of Ganoderma lucidum (Fr) P. Karst (KLU-M 1233) and $H$. erinaceus (KLU-M 1232) were obtained from Ganofarm Sdn Bhd. Pleurotus giganteus (KLU-M 1227) was provided by Nas Agro Farm and Dong Foong Biotech. Freeze dried powder of Cordyceps militaris (L.:Fr.) Link and L. rhinocerotis were purchased from BioFact Life Sdn Bhd and Ligno Biotek Sdn Bhd, respectively. Pleurotus pulmonarius (Fr.) Quél. (KLU-M 1309) and Gingko biloba extracts were obtained from Reishilab Sdn Bhd, Selangor. Wild Ganoderma neo-japonicum Imazeki 1939 (KLU-M 1231) was collected from forest in Ulu Grik, Perak, Malaysia. Ganoderma neo-japonicum was used as traditional medicine by the indigenous people in Malaysia. Grifola frondosa (Dicks.: Fr.) S.F. Gray (KLU-M 1229) imported from Japan was obtained from supermarkets in Selangor, Malaysia. Lycium barbarum (wolfberry), a traditional Chinese medicine was purchased from a Chinese medicine shop in Selangor, Malaysia and deposited in University of Malaya herbarium. Curcumin was purchased from NatXtra, Synthite Co., India.

\section{Chemicals}

Phosphate buffered saline (PBS), [3-(4,5-dimethythiazol2-yl)-2,5-diphenyltetrazolium bromide] (MTT), dimethyl sulfoxide (DMSO), nerve growth factor (NGF) from murine submaxillary gland, 3-amino-7-dimethylamino-2-methyl-phenazine hydrochloride (neutral red), and foetal bovine serum (FBS) were obtained from Sigma Co. (St. Louis, MO, USA).

\section{Cell culture}

Mouse neuroblastoma cells (N2a, ATCC CCL-131) and mouse embryonic fibroblast cells (BALB/c 3T3, ATCC clone A31) were purchased from American Type Culture Collection (ATCC; MD, USA). N2a cells were cultured in Eagle's minimum essential medium (MEM) with Lglutamine (PAA) supplemented with $10 \%(\mathrm{v} / \mathrm{v})$ heatinactivated foetal bovine serum (PAA), $100 \mathrm{U} / \mathrm{ml}$ penicillin, and $100 \mu \mathrm{g} / \mathrm{ml}$ streptomycin. 3T3 fibroblasts were maintained in Dulbecco's modified Eagle's medium (DMEM) with L-glutamine (high glucose at $4.5 \mathrm{~g} / \mathrm{l}$ ) supplemented with $10 \%$ FBS. All the cells were maintained at $37^{\circ} \mathrm{C}$ and $5 \% \mathrm{CO}_{2}$ in a humidified atmosphere. N2a cells were subcultured at $3-4$ days intervals while 3T3 cells were routinely passaged every $2-3$ days. For preservation, the cells were frozen at $-70^{\circ} \mathrm{C}$ liquid nitrogen in complete medium supplemented with $5 \%(\mathrm{v} / \mathrm{v})$ dimethyl sulfoxide (DMSO; Sigma) as a cryoprotecting agent.

\section{Preparation of mushroom extracts}

The fresh fruiting bodies of $P$. giganteus, $P$. pulmonarius, $H$. erinaceus, and G. frondosa were sliced, frozen and then freeze-dried for two days. The freeze-dried fruiting bodies were then ground to powder and kept at $4-8^{\circ} \mathrm{C}$. For aqueous extraction, the freeze dried powder was soaked in distilled water $(1: 20, \mathrm{w} / \mathrm{v})$ at room temperature and $200 \mathrm{rpm}$ in a shaker for $24 \mathrm{~h}$. The mixture was then double boiled in water bath for $30 \mathrm{~min}$, cooled and then filtered (Whatman No. 4). The resulting aqueous extracts were freeze-dried and kept at $-20^{\circ} \mathrm{C}$ prior to use. The process was repeated for the freeze-dried powder of $C$. militaris and L. rhinocerotis sclerotia. For ethanol extraction, the freeze dried powder was soaked in 95\% ethanol at room temperature for three days and the process was repeated three times. The solvent was then evaporated using a rotary evaporator (Eyela N-1000, USA) to give a brownish viscous extract.

\section{Neurite outgrowth assay}

N2a cells were seeded in 24-well culture plate at an initial density of 5,000 cells per well containing complete growth medium (1 ml/well) and incubated overnight. Concentrations of NGF ranging from $5-100 \mathrm{ng} / \mathrm{ml}(\mathrm{w} / \mathrm{v})$ were tested to determine the optimum concentration that stimulates maximum neurite outgrowth. The optimum concentration was then used as a positive control throughout the subsequent assays. Aqueous and ethanol mushroom extracts were stocked at $10 \mathrm{mg} / \mathrm{ml}$ and were subsequently dissolved in sterile distilled water or DMSO, to the appropriate concentrations. The final concentration of DMSO in the assays was $0.1-0.25 \%$. To induce cell differentiation, the complete medium was carefully replaced with $5 \%$ serum medium before exposure to mushroom extracts at $10-50 \mu \mathrm{g} / \mathrm{ml}$. Cells with medium only served as a 
Table 1 Medicinal mushrooms used in this study, their common names, and culinary nature

\begin{tabular}{|c|c|c|c|c|c|c|c|c|}
\hline Mushroom species & $\begin{array}{l}\text { Voucher } \\
\text { number }\end{array}$ & $\begin{array}{l}\text { Common } \\
\text { names }\end{array}$ & $\begin{array}{l}\text { Local names } \\
\text { (in Malay) }\end{array}$ & Part used & $\begin{array}{l}\text { Edible/ } \\
\text { culinary }\end{array}$ & $\begin{array}{l}\text { Wild/ } \\
\text { cultivated }\end{array}$ & Medicinal properties & References \\
\hline Pleurotus giganteus & KLU -M 1227 & $\begin{array}{l}\text { Zhudugu, cow's stomach } \\
\text { mushroom }\end{array}$ & $\begin{array}{l}\text { Cendawan seri pagi } \\
\text { (morning glory), perut } \\
\text { lembu (cow's stomach) }\end{array}$ & Fruiting body & Culinary & Cultivated & $\begin{array}{l}\text { Antioxidant, neurite } \\
\text { outgrowth simulation }\end{array}$ & {$[10,13]$} \\
\hline Pleurotus pulmonarius & KLU-M 1309 & Grey oyster mushroom & $\begin{array}{l}\text { Cendawan tiram kelabu } \\
\text { (grey oyster) }\end{array}$ & Fruiting body & Culinary & Cultivated & Antioxidant, anti-diabetic & [14] \\
\hline Lignosus rhinocerotis & $\begin{array}{l}\text { Purchased from } \\
\text { Ligno Biotek Sdn } \\
\text { Bhd }\end{array}$ & Tiger milk mushroom, & $\begin{array}{l}\text { Cendawan susu rimau } \\
\text { (tiger's milk) }\end{array}$ & $\begin{array}{l}\text { Sclerotium and } \\
\text { mycelium }\end{array}$ & $\begin{array}{l}\text { Non-culinary but } \\
\text { edible }\end{array}$ & Cultivated & $\begin{array}{l}\text { Anticancer, anti-inflammatory, } \\
\text { neurite outgrowth stimulation }\end{array}$ & {$[8,15]$} \\
\hline Hericium erinaceus & KLU-M 1232 & $\begin{array}{l}\text { Monkey's head mushroom, } \\
\text { lion's mane mushroom, } \\
\text { Yamabushitake }\end{array}$ & $\begin{array}{l}\text { Cendawan bunga kubis } \\
\text { (cauliflower) }\end{array}$ & Fruiting body & Culinary & Cultivated & $\begin{array}{l}\text { Anti-ulcer, neurite outgrowth } \\
\text { stimulation }\end{array}$ & {$[7,16-18]$} \\
\hline Ganoderma lucidum & KLU-M 1233 & Lingzhi, reishi & $\begin{array}{l}\text { Cendawan merah } \\
\text { (red mushroom) }\end{array}$ & Fruiting body & $\begin{array}{l}\text { Non-culinary but } \\
\text { edible }\end{array}$ & Cultivated & Anticancer, neuroprotection & [19] \\
\hline $\begin{array}{l}\text { Ganoderma } \\
\text { neo-japonicum }\end{array}$ & KLU-M 1231 & Purple reishi & $\begin{array}{l}\text { Cendawan senduk } \\
\text { (cobra mushroom) }\end{array}$ & Fruiting body & $\begin{array}{l}\text { Non-culinary but } \\
\text { edible }\end{array}$ & Wild & $\begin{array}{l}\text { Antioxidant, antihepatoxic, } \\
\text { neurite outgrowth stimulation }\end{array}$ & {$[9,20]$} \\
\hline Cordyceps militaris & $\begin{array}{l}\text { Purchased from } \\
\text { BioFact Life Sdn } \\
\text { Bhd }\end{array}$ & $\begin{array}{l}\text { Winter worm summer } \\
\text { grass, caterpillar fungus }\end{array}$ & - & $\begin{array}{l}\text { Fruiting body } \\
\text { (ascocarp) }\end{array}$ & $\begin{array}{l}\text { Non-culinary but } \\
\text { edible }\end{array}$ & Cultivated & $\begin{array}{l}\text { Anti-inflammatory, anticancer, } \\
\text { relief respiratory disorders }\end{array}$ & [21] \\
\hline Grifola frondosa & KLU- M 1229 & $\begin{array}{l}\text { Maitake, hen of the } \\
\text { woods }\end{array}$ & Cendawan maitake & Fruiting body & Culinary & Cultivated & $\begin{array}{l}\text { Anti-inflammatory, } \\
\text { anti-cholesterol }\end{array}$ & [22] \\
\hline
\end{tabular}


negative control. All the cells were incubated for $48 \mathrm{~h}$ at $37^{\circ} \mathrm{C}, 95 \%$ air and $5 \% \mathrm{CO}_{2}$ to observe neuritogenesis activity, if any. Curcumin, G. biloba and L. barbarum extracts were also tested to compare the neurite outgrowth activities with those of mushroom extracts.

\section{Quantification of neurite bearing cells}

Five random fields (100 - 200 cells/well) were examined in each well by using a phase contrast microscope (20x magnifications) equipped with QImaging Go-3 camera (QImaging, Canada). Neurite length was measured in at least 30 cells in randomly chosen fields by using image processor system Image-Pro Insight (MediaCybernetics, $\mathrm{MD})$. The number of neurite outgrowths, defined as axonlike extensions that were double or more than the length of the cell body diameter was recorded. The percentage of neurite bearing cells (\%) is the number of neurite bearing cells divided by the total number of cells in a field and then multiplied by $100 \%$. At least three independent experiments were conducted and results were expressed as mean \pm standard deviation (S.D).

\section{Fluorescence immunocytochemistry study}

The axon-like extensions were confirmed as neurite outgrowth by immunofluorescence study. N2a cells were seeded in 12-well $\mu$-dishes (ibidi, Martinsried, Germany) and were exposed to treatments for $48 \mathrm{~h}$. The cells were fixed with 4\% paraformaldehyde in PBS (pH 7) for $20 \mathrm{~min}$. After two washes with PBS, the cells were incubated with rabbit anti-neurofilament 200 polyclonal antibody (1:80 in $10 \%$ sheep serum as blocking buffer) for $1 \mathrm{~h}$. The cells were washed and then incubated in a mixture of fluorescein isothiocyanate (FITC)-conjugated secondary antibody and sheep anti-rabbit IgG (1:160 in blocking buffer) for $2 \mathrm{~h}$ at room temperature in the dark. The cells were then washed three times. 4'-6-diamidino-2- phenylindole (DAPI) was used to counter stain the nuclei. Images were observed under a fluorescent microscope (Nikon Eclipse 80i microscope).

\section{Evaluation of embryo- and/or neurotoxic effects of mushroom extracts}

MTT [3-(4,5-dimethylthiazol-2-yl)-2,5-diphenyltetrazolium bromide] assay

N2a and 3T3 cells $\left(1 \times 10^{4}\right)$ per well were seeded in 96-well plates. After incubation for $24 \mathrm{~h}$, different concentrations of mushroom extracts $(0-5 \mathrm{mg} / \mathrm{ml})$ dissolved in phenol red free culture medium were added to each well. The samples were incubated for $24 \mathrm{~h}$ at $37^{\circ} \mathrm{C}$ under humidified atmosphere of $5 \% \mathrm{CO}_{2}$ and $20 \mu \mathrm{l} \mathrm{MTT}(5 \mathrm{mg} / \mathrm{ml})$ was added to each well. The crystal dyes which were up-taken by the cells were then dissolved with DMSO. Absorbance was measured at $570 \mathrm{~nm}$ in a microplate reader (Tecan, Austria) using $630 \mathrm{~nm}$ as a reference wavelength. All measurements were done in triplicates, and at least three independent experiments were carried out. To calculate $\mathrm{IC}_{50}$ values which estimated the concentration of mushroom extract that caused $50 \%$ inhibition of proliferation (viability) in N2a and 3T3 cells, Probit analysis was conducted using SPSS 17.0 (SPSS Science Inc., Chicago, IL).

\section{Neutral red uptake assay}

Neutral red medium $(40 \mu \mathrm{g} / \mathrm{ml})$ was prepared fresh before use by diluting the neutral red stock $(4 \mathrm{mg} / \mathrm{ml})$ with phenol red free culture medium. Neutral red medium was centrifuged at $1800 \mathrm{rpm}$ for $10 \mathrm{~min}$ to remove any precipitated dye crystals before use. After cell seeding and treatment $(0-5 \mathrm{mg} / \mathrm{ml})$, the medium was discarded and replaced with equal amount of neutral red medium to each well of the plate. The plate was then incubated for $2 \mathrm{~h}$. The neutral red medium was then removed and the cells were washed quickly with adequate amount of PBS. A total of $100 \mu \mathrm{l}$ of neutral red solubilising solution (1\% acetic acid in 50\% ethanol) was added to each well and allowed to stand for 10 minutes at room temperature until the neutral red extracted from the cells reached a homogeneous solution. The absorbance at a wavelength of $540 \mathrm{~nm}$ with $690 \mathrm{~nm}$ of background absorbance was spectrophotometrically measured (Tecan, Austria). The experiment was repeated at least three different times.

\section{Lactate dehydrogenase (LDH) release assay}

After cell seeding and treatment with mushroom extracts $(0-5 \mathrm{mg} / \mathrm{ml})$, the culture plates were centrifuged at 1500 rpm for 5 minutes and $50 \mu \mathrm{l}$ of supernatant was then transferred to a new plate for $\mathrm{LDH}$ analysis according to manufacturer instruction (Sigma). To each well, $100 \mu \mathrm{l}$ of LDH mixture solution comprising of LDH assay substrate, dye and cofactor was added and incubated at room temperature for $30 \mathrm{~min}$. The reaction was stopped by adding $10 \mu \mathrm{l}$ of $1 \mathrm{~N} \mathrm{HCl}$ to each well. Absorbance was spectrophotometrically measured at $490 \mathrm{~nm}$ with background absorbance at $690 \mathrm{~nm}$. Triton X-100 (0.5\%, Scharlau) was used as a positive control and was thus set to $0 \%$ viability representing a $100 \%$ cell death.

\section{Statistical analysis}

All the experimental data are expressed in mean \pm standard deviation (S.D). Statistical differences between groups were analysed and calculated by one-way analysis of variance (ANOVA) from at least three independent experiments. This was followed by Duncan's multiple range tests. $P<0.05$ was considered to be significant between groups. 


\section{Results}

The effects of NGF on neurite outgrowth activity in N2a cells

Nerve growth factor induced neurite outgrowth of N2a in a dose-dependent manner (Figure 1). After $48 \mathrm{~h}$ of NGF stimulation, the percentage of neurite bearing cells increased significantly $(p<0.05)$ to $26.1 \pm 1.8 \%$ in $\mathrm{N} 2 \mathrm{a}$ cells treated with $50 \mathrm{ng} / \mathrm{ml}$ NGF when compared to negative control $(7.6 \pm 2.5 \%)$. At $60 \mathrm{ng} / \mathrm{ml}$ of NGF, the percentage of neurite bearing cells significantly decreased to $12.2 \pm 2.1 \%(p<0.05)$. Based on these findings, the optimised concentration of NGF (50 ng/ml) was selected for the following experiments as a positive control.

\section{The effects of different mushroom extracts on neurite outgrowth activity in N2a cells}

The positive control (NGF) recorded $26.4 \pm 3.6 \%$ of neurite-bearing cells (Figure 2). The extraction yield of extracts from the mushrooms are summarised in Table 2. The percentage of neurite bearing cells after treatment with aqueous extracts of $G$. lucidum (38.4 $\pm 4.2 \%)$, L. rhinocerotis $(38.1 \pm 2.6 \%)$, and ethanol extract of C. militaris $(35.8 \pm 3.4 \%)$ were significantly higher $(p<0.01)$ than NGF control by approximately 1.45-, 1.44- and 1.35-fold, respectively. Aqueous extracts of G. frondosa $(33.7 \pm 1.5 \%)$ and $P$. giganteus $(33.4 \pm 4.6 \%)$ were also shown to induce significantly $(p<0.05)$ higher neurite bearing cells compared to the NGF control. Meanwhile, the aqueous extracts of $L$. rhinocerotis mycelium, $H$. erinaceus, G. neo- japonicum, P. pulmonarius, as well as ethanol extracts of $H$. erinaceus, $P$. pulmonarius and $P$. giganteus showed varied neurite outgrowth stimulatory effects with average neurite bearing cells ranging from $26.4 \pm 5.4 \%$ to $29.6 \pm 2.2 \%$. Further, these extracts showed no significant difference when compared to NGF control $(p>0.05)$. Among the plant extracts tested, wolfberry

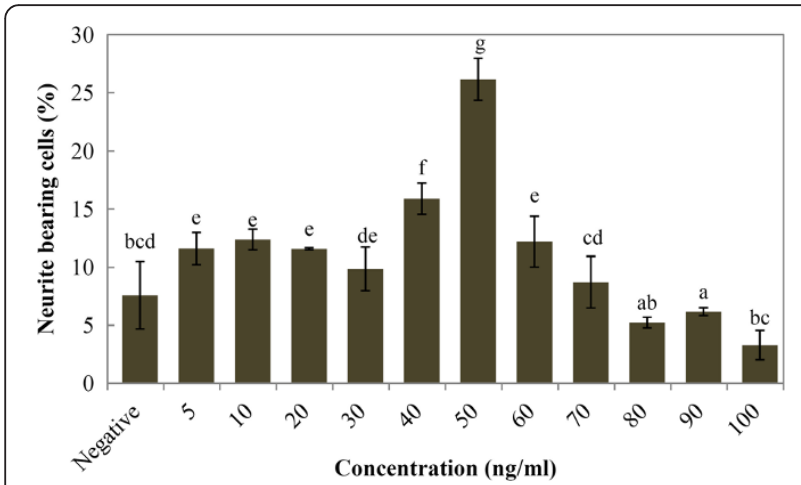

Figure 1 Effects of different NGF concentrations (5 - $100 \mathrm{ng} / \mathrm{ml}$ ) on stimulation of neurite outgrowth using differentiating N2a cells as an in vitro model. The results shown represent the mean $\pm S D ; n=3$. Means not sharing a common letter were significantly different at $p<0.05$. extract did not show any neurite outgrowth activity. The percentage of neurite bearing cells obtained after treatment with $20 \mu \mathrm{g} / \mathrm{ml}$ of ethanol extract of G. biloba $(30.3 \pm 2.5 \%)$ was better than curcumin which gave $26.4 \pm 5.4 \%$ at $20 \mu \mathrm{g} / \mathrm{ml}$. The five different mushroom extracts (G. lucidum, L. rhinocerotis, P. giganteus, G. frondosa and C. militaris) each at $20 \mu \mathrm{g} / \mathrm{ml}$ were selected for neurofilament staining.

The mean diameter of N2a cell body was found to be $19.45 \pm 0.72 \mu \mathrm{m}$ (Figure 3 ). To qualify as a "neurite", the axon-like extension needs to be double or more than the cell body length of N2a. The average neurite length of NGF-stimulated cells was $78.58 \pm 18.6 \mu \mathrm{m}$, which is approximately 4-time longer than the cell body. Cells treated with aqueous extract of G. lucidum were found to develop the longest mean neurite length i.e. $121.51 \pm 28.6$ $\mu \mathrm{m}$ (6.25-time longer than cell body), followed by aqueous extract of $P$. giganteus which recorded mean neurite length of $116.72 \pm 29.5 \mu \mathrm{m}$ (5.99-time longer than cell body). Figure 4 shows the morphology of differentiating $\mathrm{N} 2 \mathrm{a}$ cells with neurites after $48 \mathrm{~h}$ of treatment with $50 \mathrm{ng} / \mathrm{ml} \mathrm{NGF} \mathrm{(a)} \mathrm{and} 20 \mu \mathrm{g} / \mathrm{ml}$ of aqueous extracts of G. lucidum (b), L. rhinocerotis (c), P. giganteus (d) and G. frondosa (e); as well as ethanol extract of C. militaris (f).

\section{Immunofluorescence staining of neurofilament}

Neurofilament belongs to a class of intermediate filament found in neuronal cells that provides specific support for axons. There is a direct relationship between neurite outgrowth and neurofilament expression as neurofilament protein levels increase with differentiation of cell lines [23]. Figure 5 shows the immunocytochemical labeling of neurons. The expression of neurofilament protein during neurite outgrowth was stained green while nuclei were stained blue.

The cytotoxic effects of mushroom extracts on 3T3 and N2a by using MTT, NRU and LDH release assay

Table 3 shows the results of cytotoxicity screening of mushroom and plant extracts to N2a cells and 3T3 fibroblasts. The cytotoxicity determination are expressed as $\mathrm{IC}_{50}$ values, which is the concentration resulting in $50 \%$ inhibition of cell growth and proliferation after $24 \mathrm{~h}$ exposure. All the extracts of mushrooms and plants did not show cytotoxic effects to the two tested cell lines ( $\mathrm{IC}_{50} \geq 1 \mathrm{mg} / \mathrm{ml}$ in all cases). Three cytotoxicity endpoints were used in this experiment, which were MTT, NR uptake assay and $\mathrm{LDH}$ release assay. Interestingly, $\mathrm{IC}_{50}$ determined by NRU test and LDH test was higher than that of MTT. In general term, the ethanol extracts showed lower $\mathrm{IC}_{50}$ too. 


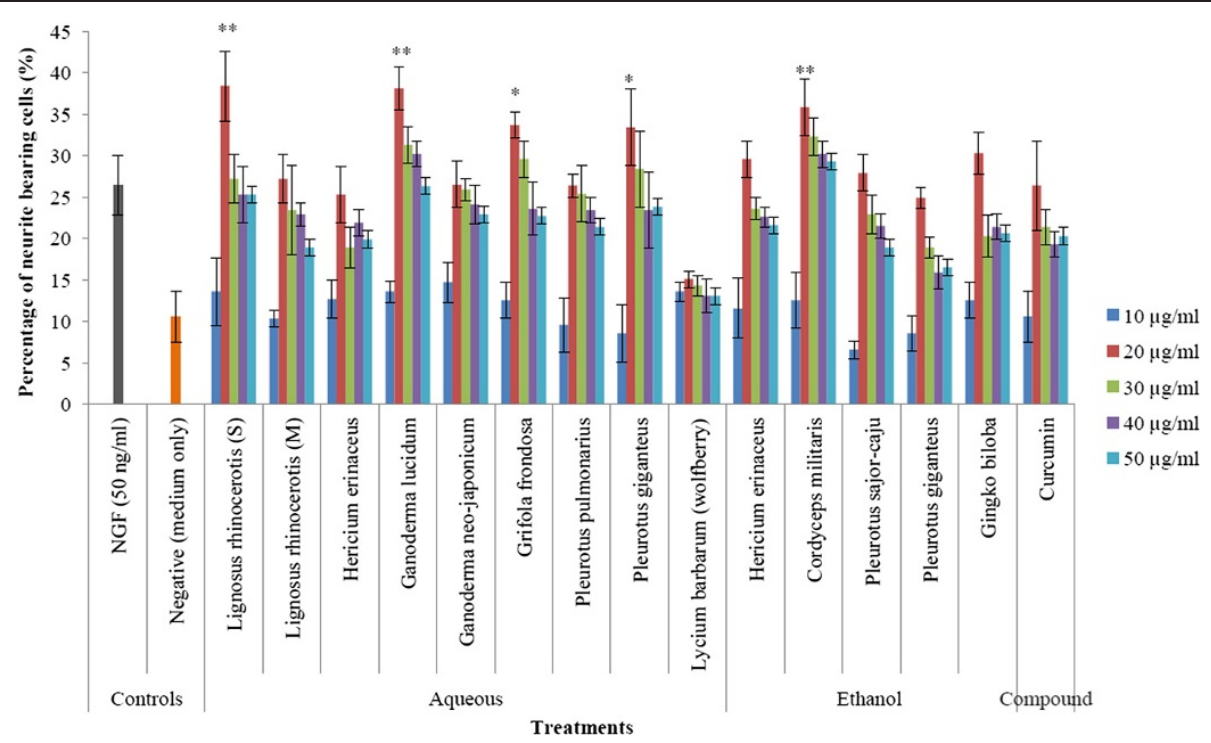

Figure 2 Percentage of neurite bearing cells after treatment of different mushroom and plant extracts. ${ }^{*} p<0.05,{ }^{* * *} p<0.01$ versus the positive control (NGF). (S) = sclerotium, (M) = mycelium.

\section{Discussions}

Eight species of medicinal mushrooms were investigated and categorised into two groups: culinary and nonculinary. The former group represents mushrooms that can be used for culinary purposes like preparing meal and cooking, especially from the fruiting bodies. This group (culinary-medicinal mushrooms) comprised of $P$. giganteus, $P$. pulmonarius, $H$. erinaceus, and $G$. frondosa. Medicinal mushrooms of no culinary properties are appreciated for their pharmacological merits and are

Table 2 Extraction yield of aqueous and ethanol extracts from the studied mushrooms

\begin{tabular}{lll}
\hline Mushrooms & Extract & Yield (\%, w/w) \\
\hline Lignosus rhinocerotis (S) & Aqueous & 3.56 \\
Lignosus rhinocerotis (M) & & 4.65 \\
Hericium erinaceus & & 8.56 \\
Ganoderma lucidum & 3.67 \\
Ganoderma neo-japonicum & & 5.75 \\
Grifola frondosa & & 3.54 \\
Pleurotus pulmonarius & & 3.60 \\
Pleurotus giganteus & & 6.70 \\
Hericium erinaceus & Ethanol & 4.50 \\
Cordyceps militaris & & 3.45 \\
Pleurotus pulmonarius & & 6.70 \\
Pleurotus giganteus & & 5.30 \\
Lycium barbarum (wolfberry) & Aqueous & 9.76 \\
Gingko biloba & Ethanol & n.d \\
\hline
\end{tabular}

$(\mathrm{S})=$ sclerotium,$(\mathrm{M})=$ mycelium. n.d. = not determined. not cooked as a meal. The fruiting bodies or sclerotia are often handpicked, ground to powder and subjected to various extraction methods before being used as a traditional medication [24]. L. rhinocerotis, G. lucidum, G. neo-japonicum, and C. militaris are non-culinary medicinal mushrooms.

Ganoderma lucidum (also known as Lingzhi in Chinese or Reishi in Japanese) has been widely investigated for its potential therapeutic benefits and longevity. Our results showed that aqueous extract of G. lucidum promoted neuritogenesis in N2a cells with $38.4 \pm 4.2 \%$ of neurite

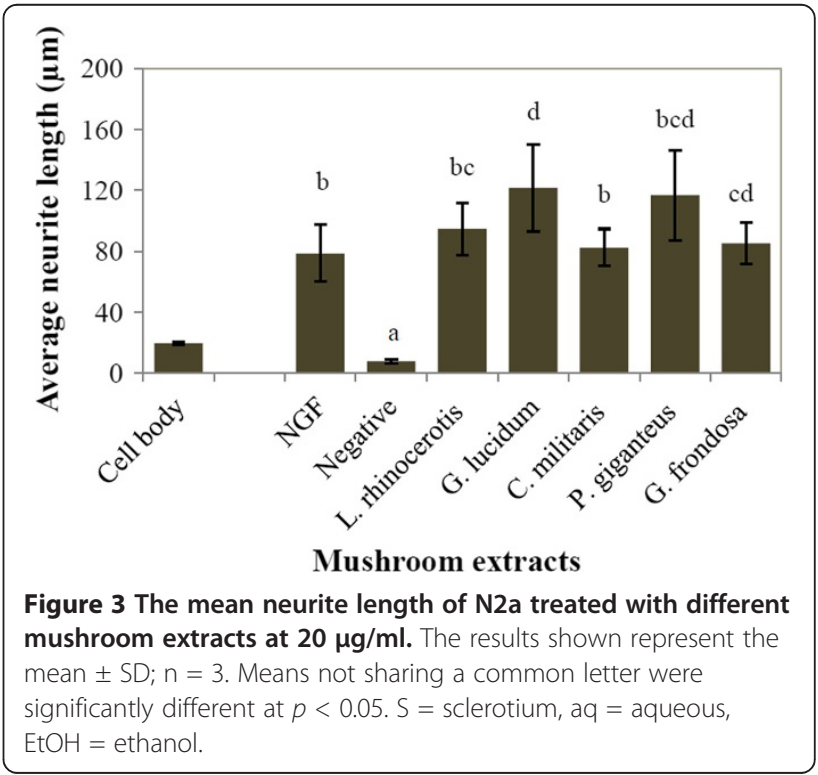



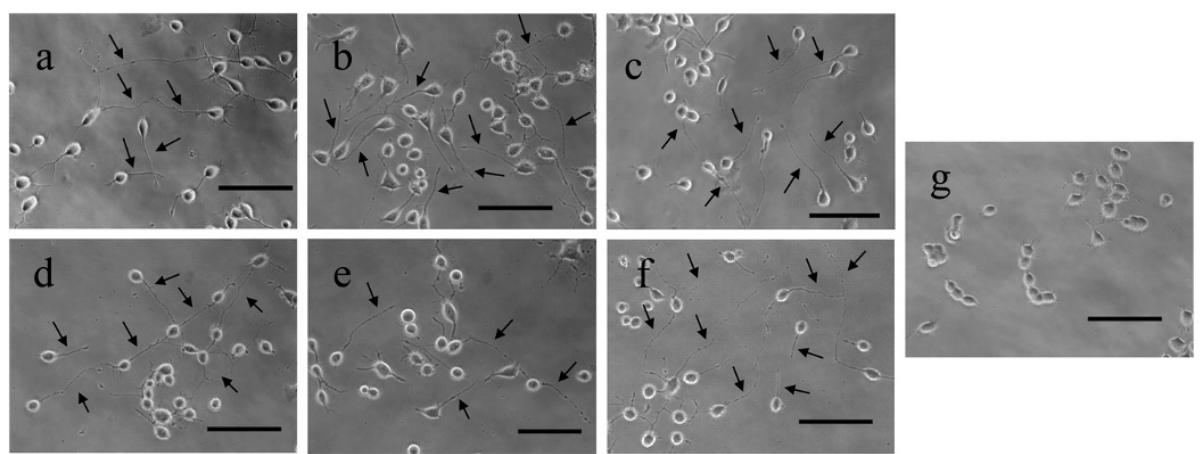

Figure 4 Phase-contrast photomicrographs showing the effects of (a) NGF, (b) G. lucidum, (c) L. rhinocerotis, (d) P. giganteus, (e) G. frondosa, and (f) C. militaris on the morphology of differentiating N2a cells after $48 \mathrm{~h}$. Untreated cells serve as control (g) and only contained 5\% FBS as vehicle. Arrows indicate typical neurites of N2a. Scale bar represents $20 \mu \mathrm{m}$. Photomicrographs of representative microscope fields were taken with a 20x objective.

bearing cells. This agrees with the finding of Cheung et al. [25] who showed that Ganoderma extract contained NGFlike compounds that mediated the neuronal differentiation and elongation of rat pheochromocytoma (PC12) cells. The Ganoderma neuroactive constituents that accounted for neurite outgrowth activity are triterpenoids, such as lucidenic acid [26], 7-oxo-ganoderic acid Z, ganolucidic acid A, methyl ganoderic acid A, ganoderic acid S1, and 4,4,14 $\alpha$-trimethyl-5 $\alpha$-chol-7,9(11)-dien-3-oxo-24oic acid [27]. Further, the water-soluble polysaccharides of G. lucidum were shown to significantly $(p<0.05)$ reduce neuronal cell death and apoptosis of rat primary cortical neurons (model of brain cerebral ischemia) induced by oxygen/glucose deprivation treatment [19]. Ganoderma extracts may also provide mitigation to Parkinson's disease as it was shown to prevent dopaminergic neuron degeneration by attenuating the pro-inflammatory response of microglial cells [28].

The tiger milk mushroom, $L$. rhinocerotis has been described as the national treasure of Malaysia as this macrofungus is rare and is often used as folk remedy to treat a variety of diseases. Consistent with our previous study [8], the sclerotia of L. rhinocerotis improved neurite outgrowth in N2a. Interestingly, in the present study, the sclerotial extract $(38.4 \pm 4.2 \%$ of neurite bearing cells) performed better than the mycelial extract $(27.2 \pm 2.9 \%)$. However, the active components in $L$. rhinocerotis that play the role in neurite outgrowth activity need further investigation. Lee et al. [15] highlighted that the protein or carbohydrate/protein complex of the cold water scerotial extract $\left(4^{\circ} \mathrm{C}\right)$ is responsible for the antiproliferative activity against human breast and lung carcinoma. In this study, a hot water extraction approach was employed and we hypothesise that polysaccharides or triterpenoids rather than peptides are involved in the neurite outgrowth stimulatory activity of $L$. rhinocerotis.

Wild Pleurotus giganteus has been reported to be consumed by the indigenous tribes of Semai, Temuan, and Jakun in Malaysia [29]. This wild mushroom has been successfully domesticated for large scale production and is
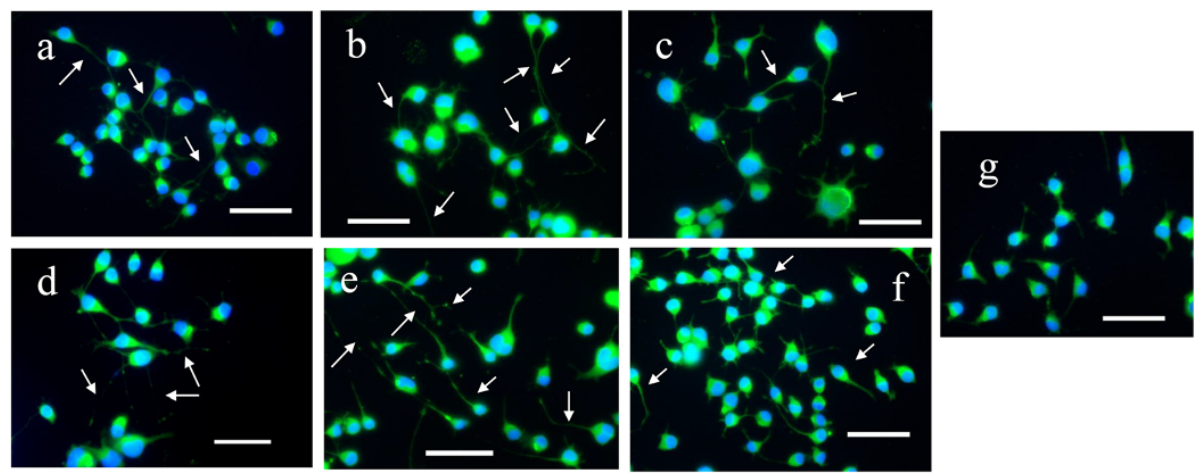

Figure 5 Immunocytochemical staining of neurofilament in N2a cells treated with (a) NGF, (b) G. lucidum, (c) L. rhinocerotis, (d) P. giganteus, (e) G. frondosa, and (f) C. militaris, and untreated cells as control (g). DAPI stains for nuclei blue, while anti-neurofilament $200 \mathrm{kD}$ labeled with FITC stains neuronal cells green. Scale bar represents $20 \mu \mathrm{m}$. Arrows indicate neurite outgrowth. Photomicrographs of representative microscope fields were taken with a 20x objective. 
Table 3 IC $_{50}$ values obtained by using different cytotoxicity assays- MTT, NRU and LDH release

\begin{tabular}{|c|c|c|c|c|c|c|c|c|}
\hline \multirow[t]{3}{*}{ Mushroom/Plant } & \multirow[t]{3}{*}{ Species } & \multirow[t]{3}{*}{ Extracts } & \multirow{2}{*}{\multicolumn{3}{|c|}{$\begin{array}{l}\text { Neuroblastoma 2a cells } \\
\mathrm{IC}_{50}(\mathrm{mg} / \mathrm{ml}) \text { after } 24 \mathrm{~h}\end{array}$}} & \multirow{2}{*}{\multicolumn{3}{|c|}{$\begin{array}{l}3 \mathrm{~T} 3 \text { embryonic fibroblast } \\
\mathrm{IC}_{50}(\mathrm{mg} / \mathrm{ml}) \text { after } 24 \mathrm{~h}\end{array}$}} \\
\hline & & & & & & & & \\
\hline & & & MTT & NRU & LDH & MTT & NRU & LDH \\
\hline \multirow{13}{*}{$\begin{array}{l}\text { Culinary/medicinal } \\
\text { mushroom }\end{array}$} & Pleurotus giganteus & Aqueous & $4.07 \pm 0.67^{e}$ & $6.95 \pm 1.00^{9}$ & - & $2.16 \pm 0.05^{c}$ & $2.67 \pm 0.47^{d}$ & - \\
\hline & Pleurotus pulmonarius & & $2.85 \pm 0.06^{\mathrm{cd}}$ & $2.13 \pm 0.87^{\text {cdef }}$ & - & $1.75 \pm 0.14^{b c}$ & $2.60 \pm 0.55^{d}$ & - \\
\hline & $\begin{array}{l}\text { Lignosus rhinocerotis } \\
\text { (sclerotium) }\end{array}$ & & $3.27 \pm 0.77^{d}$ & $2.72 \pm 0.65^{\mathrm{ef}}$ & - & $5.63 \pm 0.06^{e}$ & $5.93 \pm 0.05^{f}$ & - \\
\hline & Lignosus rhinocerotis & & $2.43 \pm 0.12^{c}$ & $1.75 \pm 0.18^{\mathrm{abc}}$ & - & $5.23 \pm 0.17^{e}$ & $5.60 \pm 0.1^{f}$ & - \\
\hline & (mycelium) & & & & & & & \\
\hline & Hericium erinaceus & & $2.60 \pm 0.52^{c d}$ & $2.85 \pm 0.56^{\mathrm{e}}$ & - & $3.43 \pm 0.29^{d}$ & $3.53 \pm 0.06^{\mathrm{e}}$ & - \\
\hline & Ganoderma lucidum & & $1.35 \pm 0.03^{\mathrm{a}}$ & $1.52 \pm 0.17^{\mathrm{ab}}$ & $2.20 \pm 0.52^{\mathrm{ab}}$ & $1.19 \pm 0.06^{\mathrm{ab}}$ & $1.35 \pm 0.02^{\mathrm{ab}}$ & $1.50 \pm 0.08^{a}$ \\
\hline & $\begin{array}{l}\text { Ganoderma } \\
\text { neo-japonicum }\end{array}$ & & $1.17 \pm 0.006^{\mathrm{a}}$ & $1.11 \pm 0.03^{\mathrm{a}}$ & $2.00 \pm 0.53^{\mathrm{ab}}$ & $1.47 \pm 0.37^{\mathrm{ab}}$ & $1.78 \pm 0.56^{b c}$ & $1.58 \pm 0.44^{a}$ \\
\hline & Grifola frondosa & & $2.72 \pm 0.08^{\mathrm{cd}}$ & $4.60 \pm 1.10^{f}$ & - & $6.67 \pm 0.87^{f}$ & $7.60 \pm 0.1^{9}$ & - \\
\hline & Pleurotus giganteus & Ethanol & $2.43 \pm 0.10^{c}$ & $2.81 \pm 0.15^{\mathrm{e}}$ & $5.8 \pm 0.10^{c}$ & $1.66 \pm 0.56^{\mathrm{bc}}$ & $1.96 \pm 0.42^{c}$ & $1.73 \pm 0.48^{\mathrm{a}}$ \\
\hline & Pleurotus pulmonarius & & $2.30 \pm 0.72^{\mathrm{bc}}$ & $2.64 \pm 0.16^{\text {def }}$ & $2.53 \pm 0.96^{b c}$ & $1.27 \pm 0.06^{\mathrm{ab}}$ & $1.48 \pm 0.05^{\mathrm{abc}}$ & $1.67 \pm 0.12^{a}$ \\
\hline & Hericium erinaceus & & $2.47 \pm 0.50^{c}$ & $1.61 \pm 0.51^{\mathrm{ab}}$ & $2.10 \pm 0.72^{\mathrm{ab}}$ & $1.31 \pm 0.03^{\mathrm{ab}}$ & $1.84 \pm 0.57^{\mathrm{bc}}$ & $1.47 \pm 0.31^{a}$ \\
\hline & Cordyceps militaris & & $1.65 \pm 0.015^{\mathrm{ab}}$ & $1.81 \pm 0.10^{\mathrm{abcd}}$ & $2.37 \pm 0.21^{\mathrm{b}}$ & $1.02 \pm 0.08^{\mathrm{a}}$ & $1.10 \pm 0.02^{\mathrm{a}}$ & $1.40 \pm 0.29^{a}$ \\
\hline \multirow[t]{3}{*}{ Medicinal plant } & Lycium barbarum & Aqueous & $4.37 \pm 1.00^{\mathrm{e}}$ & $6.96 \pm 0.73^{9}$ & - & $8.40 \pm 0.72^{9}$ & $7.86 \pm 0.06^{9}$ & - \\
\hline & Gingko biloba & Ethanol & $1.56 \pm 0.08^{\mathrm{ab}}$ & $1.66 \pm 0.11^{\mathrm{ab}}$ & $1.43 \pm 0.39^{a}$ & $1.56 \pm 0.58^{\mathrm{abc}}$ & $1.37 \pm 0.07^{\mathrm{ab}}$ & $1.78 \pm 0.07^{\mathrm{a}}$ \\
\hline & Curcumin & Compound & $1.13 \pm 0.01^{a}$ & $1.15 \pm 0.01^{\mathrm{a}}$ & $1.30 \pm 0.16^{a}$ & $1.16 \pm 0.06^{\mathrm{ab}}$ & $1.23 \pm 0.03^{\mathrm{ab}}$ & $1.60 \pm 0.22^{a}$ \\
\hline
\end{tabular}

The data represent the mean \pm SD of three determinations. Means not sharing a common letter were significantly different at $p<0.05$.

gaining popularity for culinary uses. The medicinal properties of $P$. giganteus are comparatively little as compared to P. pulmonarius (grey oyster mushroom). Recently P. giganteus (synonyms: Lentinus giganteus and Panus giganteus) was shown to have in vivo hepatoprotective effect in rat [13] and in vitro neuritogenic effects in PC12 cells [10]. On-going studies aimed at isolating and identifying the chemical constituents of the $P$. giganteus fruiting bodies indicate the presence of phenolics (caffeic acid and cinnamic acid), organic acid (succinic acid) and triterpenoids (unpublished data). The compounds may work synergistically and accounted for neuritogenesis.

Cordyceps militaris is a parasitic fungus that colonises moth larvae (Lepidoptera) and has been valued in Traditional Chinese Medicine for more than 2000 years. The major bioactive components in C. militaris include adenosine, cordycepin and polysaccharides [30]. Our finding is in agreement with the work by Lee et al. [21] where methanol extract of $C$. militaris was shown to significantly reverse the scopolamine-induced deficit in memory of rat and improve neurite outgrowth in N2a. Similar to our results, lysophosphatidylethanolamine isolated from $G$. frondosa (Maitake) was also reported to induce neuronal differentiation in PC12 cells, causing up-regulation of neurofilament $\mathrm{M}$ expression of PC12 cells [22].

It is well known that N2a cells, upon the withdrawal of serum, differentiate and elaborate neurites [31,32].
This well-defined neuronal model is often employed for studies relating to neuronal differentiation [33]. It is also a popular cell line in studying neurotoxicity as the brain is a first target in situations such as ageing and neurodegenerative diseases [34]. NGF is the most appropriate positive control in neurite outgrowth assays as its role in neural development have been characterised extensively as supported by Sofroniew et al. [35]. The therapeutic application of neurotrophins like nerve growth factor (NGF) is not possible as NGF cannot penetrate the blood-brain barrier. Studies indicate that lower-molecularweight molecules may be a promising alternative for therapeutic intervention, for example, $\alpha$-phenyl-N-tertbutylnitron [36]. However, most of the experiments testing natural products have been conducted in vitro, and few studies evaluated these compounds in the brain in vivo. Our previous study showed that aqueous extract of $P$. giganteus induced neuronal differentiation of PC12 cells via the activation of extracellular signal-regulated kinase (ERK) and phosphatidylinositol-3-kinase-Akt (PI3K/Akt) signaling pathways [10]. In fact, the most studied pathway controlling the consolidation of neurites involves signaling through neurotrophin receptors to a Rasdependent, mitogen-activated protein kinase (MAPK) cascade [33]. At present, the precise neuritogenic signal transduction pathway involved in the actions of NGF, serum withdrawal, and the mushroom extracts is yet to be 
elucidated. It is anticipated that mushroom extracts (comprising of neuroactive polysaccharides or triterpenoids) under certain condition (serum deprivation) participate in triggering NGF signals, hence activating the downstream neuronal responses to axonal growth [37].

It is important that functional and health food remedies recommended for the prevention or treatment of diseases undergo safety assessment. Today, a number of natural products with potential biomedical application are being launched, although some could be potentially toxic when ingested at high doses or in combination with other medications [38]. Our results indicated that no cytotoxicity was detected for the concentrations tested. Notably, ethanol extract of $C$. militaris showed the lowest $\operatorname{IC}_{50}(p<0.05)$ value against 3T3 fibroblast. Similarly, curcumin although was reported beneficial in neuroprotection [39], the $\mathrm{IC}_{50}$ value detected against $\mathrm{N} 2 \mathrm{a}$ was the lowest by means of MTT, NRU and LDH assays. Elsewhere, in vivo toxicity evaluation of Ganoderma boninense (Pat.) was carried out [40] and a significant toxicity $\left(\mathrm{IC}_{50}=640 \mu \mathrm{g} / \mathrm{ml}\right.$ ) against Artemia salina (brine shrimp) was demonstrated after 24 h. However, Ganoderma extract is granted safe on shortterm exposure. Conversely, in vivo toxicity profiling of total triterpene fraction from G. lucidum against Swiss albino mice showed that ganoderma triterpenes did not possess significant toxicity [41] and administration of G. lucidum $\beta$-glucan ( $2000 \mathrm{mg} / \mathrm{kg}$ body weight/day) to Sprague Dawley rats did not cause toxicological abnormality [42]. Mutagenicity studies by means of Salmonella typhimurium also did not reveal any genotoxicity. Meanwhile, sub-acute toxicity study of the sclerotial powder of $L$. rhinocerotis by using rat model showed no treatment-related toxicity at $1000 \mathrm{mg} / \mathrm{kg}$ [43]. Taken together, beneficial mushroom extracts hardly exert any significant toxicity.

We have chosen more than one cytotoxicity assay namely MTT, NRU and LDH release assay to determine in vitro cell viability in order to increase the reliability of the results obtained and also to avoid over- or underestimation of the mushroom or plant toxicity. The mechanisms of the chosen assays are different. While MTT is based on the enzymatic conversion of MTT in the mitochondria, NRU assay is based on the dye uptake capability by lysosomes [44]. Both served as colorimetric assays, whereby viable and uninjured cells stain blue and red, for MTT and NRU assays, respectively. LDH release assay, on the other hand is based on the release of the enzyme into the culture medium after the disruption of cell membrane [45]. It is noteworthy that the toxicity profiles detected by the three different assays generally followed a similar trend although some results were not in agreement. For instance, no $\mathrm{IC}_{50}$ values were recorded for some mushroom extracts by using LDH assays, suggesting that LDH may be the least sensitive method among the three.

\section{Conclusions}

The extracts of G. lucidum, L. rhinocerotis, P. giganteus, G. frondosa and C. militaris showed potential in promoting neurite outgrowth of differentiating N2a cells. The synergism of the various active entities in these mushroom extracts may be responsible for the neurite outgrowth activity and further experiments are warranted to isolate and identify the compounds. The signaling pathways involved is yet to be elucidated but based on our previous results, among other possibilities, phosphorylation and activation of the ERK and Akt may be involved. This study also showed the absence of embryotoxic and neurototoxic effects of the various mushroom extracts in 3T3 and N2a cells, respectively.

\section{Competing interest}

The authors declare that they have no competing interests.

\section{Authors' contributions}

CWP carried out the study, performed the data collection, data management, statistical analysis, data interpretation, and manuscript writing PD and VS conceived the study, participated in its design and coordination. MN participated in the design of the study. KHW took part in data interpretation. MN and VS contributed to conception of the design and execution of the study. All authors read and approved the final manuscript.

\section{Acknowledgement}

This research is supported by UM High Impact Research Grant UM-MOHE UM.C/625/1/HIR/MOHE/ F00002-21001 from the Ministry of Higher Education Malaysia. The authors also thank University of Malaya for Postgraduate Research Grant (PPP Grant: PV007/2012A), RG158/11AFR, and RG136/10AFR. We also thank Ernest Cheah H.K from microLAMBDA Sdn Bhd for his technical support in imaging analysis. Special thanks to Dr John James Wilson from Institute of Biological Sciences, University of Malaya for proofreading the manuscript.

\section{Author details}

${ }^{1}$ Mushroom Research Centre, Institute of Biological Sciences, Faculty of Science, University of Malaya, 50603 Kuala Lumpur, Malaysia. ${ }^{2}$ Institute of Biological Sciences, Faculty of Science, University of Malaya, 50603 Kuala Lumpur, Malaysia. ${ }^{3}$ Department of Anatomy, Faculty of Medicine, University of Malaya, 50603 Kuala Lumpur, Malaysia.

Received: 2 April 2013 Accepted: 8 October 2013 Published: 11 October 2013

\section{References}

1. Bernd P: The role of neurotrophins during early development. Gene Expr 2008, 14(4):241-250

2. Fornasiero EF, Bonanomi D, Benfenati F, Valtorta F: The role of synapsins in neuronal development. Cell Mol Life Sci 2010, 67:1383-9136.

3. Wong K-H, Naidu M, David P, Bakar R, Sabaratnam V: Neuroregenerative potential of Lion's Mane Mushroom, Hericium erinaceus (Bull.: Fr.) Pers. (Higher Basidiomycetes), in the treatment of peripheral nerve injury (Review). Int J Med Mushrooms 2012, 14(5):427-446.

4. Loers $G$, Schachner M: Recognition molecules and neural repair. J Neurochem 2007, 101(4):865-882.

5. Shulman JM, Jager PLD: Evidence for a common pathway linking neurodegenerative diseases. Nat Genet 2009, 41:1261-1262.

6. Sabaratnam V, Wong KH, Naidu M, David PR: Neuronal health-Can culinary and medicinal mushrooms help? J Trad Complem Med 2011, 3(1):62-68.

7. Wong KH, Sabaratnam V, Abdullah N, Naidu M, Keynes R: Activity of aqueous extracts of lions mane mushroom Hericium erinaceus (Bull.: Fr.) Pers. (Aphyllophoromycetideae) on the neural cell line NG108-15. Int J Med Mushrooms 2007, 9(1):57-65. 
8. Eik LF, Naidu M, David P, Wong KH, Tan YS, Sabaratnam V: Lignosus rhinocerus (Cooke) Ryvarden: A medicinal mushroom that stimulates neurite outgrowth in PC-12 cells. Evid-based Compl Alt 2012, 2012:320308.

9. Seow SLS, Naidu M, David P, Wong KH, Sabaratnam V: Potentiation of neuritogenic activity of medicinal mushrooms in rat pheochromocytoma cells. BMC Complem Altern Med 2013, 13(1):157.

10. Phan CW, Wong WL, David P, Naidu M, Sabaratnam V: Pleurotus giganteus (Berk.) Karunarathna \& K. D. Hyde: Nutritional value and in vitro neurite outgrowth activity in rat pheochromocytoma cells. BMC Complem Altern Med 2012, 12:102.

11. Genschow E, Spielmann H, Scholz G, Pohl I, Seiler A, Clemann N, Bremer S, Becker $\mathrm{K}$ : Validation of the embryonic stem cell test in the international ECVAM validation study on three in vitro embryotoxicity tests. Altern Lab Anim 2004, 32:209-244.

12. Seiler AEM, Spielmann $\mathrm{H}$ : The validated embryonic stem cell test to predict embryotoxicity in vitro. Nat Protoc 2011, 6(7):961-978.

13. Wong WL, Abdulla MA, Chua KH, Rani U, Tan YS, Sabaratnam V: Hepatoprotective effects of Panus giganteus (Berk.) Corner against thioacetamide (TAA)-induced liver injury in rats. Evid-based Compl Alt 2012, 2012:170303.

14. Kanagasabapathy G, Malek SNA, Kuppusamy UR, Vikineswary S: Chemical composition and antioxidant properties of extracts of fresh fruiting bodies of Pleurotus sajor-caju (Fr.) Singer. J Agric Food Chem 2011, 59(6):2618-2626

15. Lee ML, Tan NH, Fung SY, Tan CS, Ng ST: The antiproliferative activity of sclerotia of Lignosus rhinocerus (tiger milk mushroom). Evid-based Compl Alt 2012, 2012:697603

16. Wong KH, Sabaratnam V, Abdullah N, Kuppusamy UR, Naidu M: Effects of cultivation techniques and processing on antimicrobial and antioxidant activities of Hericium erinaceus ( Bull.: Fr.) Pers. extracts. Food Technol Biotechnol 2009, 47(1):47-55.

17. Wong KH, Naidu M, David P, Abdulla MA, Abdullah N, Kuppusamy UR, Sabaratnam $V$ : Functional recovery enhancement following injury to rodent peroneal nerve by lions mane mushroom, Hericium erinaceus (Bull.: Fr.) Pers. (Aphyllophoromycetideae). Int J Med Mushrooms 2009, 11(3):225-236

18. Wong KH, Naidu M, David P, Abdulla MA, Abdullah N, Kuppusamy UR, Sabaratnam $V$ : Peripheral nerve regeneration following crush injury to rat peroneal nerve by aqueous extract of medicinal mushroom Hericium erinaceus (Bull.: Fr) Pers. (Aphyllophoromycetideae). Evid-based Compl Alt 2010, 2011:580752.

19. Zhou Z, Tang Y, Xiang J, Wua P, Jin H, Wang Z, Morid M, Cai DF: Neuroprotective effects of water-soluble Ganoderma lucidum polysaccharides on cerebral ischemic injury in rats. J Ethnopharmacol 2010, 131(1):154-164.

20. Lin J, Lin C, Chen M, Ujiie T, Takada A: Radical scavenger and antihepatotoxic activity of Ganoderma formosanum, Ganoderma lucidum and Ganoderma neo-japonicum. J Ethnopharmacol 1995, 47:33-41.

21. Lee B, Park J, Park J, Shin HJ, Kwon S, Yeom M, Sur B, Kim S, Kim M, Lee H, Yoon $\mathrm{SH}, \mathrm{Hahm}$ DH: Cordyceps militaris improves neurite outgrowth in Neuro2a cells and reverses memory impairment in rats. Food Sci Biotechnol 2011, 20(6):1599-1608.

22. Nishina A, Kimura H, Sekiguchi A, Fukumoto R, Nakajima S, Furukawa S: Lysophosphatidylethanolamine in Grifola frondosa as a neurotrophic activator via activation of MAPK. J Lipid Res 2006, 47(7):1434-1443.

23. Flaskos J, Fowler MJ, Teurtrie C, Hargreaves AJ: The effects of carbaryl and trichlorphon on differentiating mouse N2a neuroblastoma cells. Toxicol Lett 1999, 110:79-84.

24. Tibuhwa DD: Folk taxonomy and use of mushrooms in communities around Ngorongoro and Serengeti National Park, Tanzania. J Ethnobiol Ethnomed 2012, 8:36

25. Cheung WMW, Hui WS, Chu PWK, Chiu SW, Ip NY: Ganoderma extract activates MAP kinases and induces the neuronal differentiation of rat pheochromocytoma PC12 cells. FEBS Lett 2000, 486(3):291-296.

26. Connolly JD, Hill RA: Triterpenoids. Nat Prod Rep 2003, 20(6):640-659.

27. Zhang XQ, Ip FCF, Zhang DM, Chen LX, Zhang W, Li YL, Ip NY, Ye WC: Triterpenoids with neurotrophic activity from Ganoderma lucidum. Nat Prod Res 2011, 25(17):1607-1613.

28. Zhang R, Xu S, Cai Y, Zhou M, Zuo X, Chan P: Ganoderma lucidum protects dopaminergic neuron degeneration through inhibition of microglial activation. Evid-based Compl Alt 2011, 2011:156810.
29. Lee SS, Chang YS, Noraswati MNR: Utilization of macrofungi by some indigenous communities for food and medicine in Peninsular Malaysia. Forest Ecol Manag 2009, 257(10):2062-2065.

30. Yu HM, Wang BS, Huang SC, Duh PD: Comparison of protective effects between cultured Cordyceps militaris and natural Cordyceps sinensis against oxidative damage. J Agric Food Chem 2006, 54:3132-3138.

31. Wang X, Wang Z, Yao Y, Li J, Zhang X, Li C, Cheng Y, Ding G, Liu L, Ding Z: Essential role of ERK activation in neurite outgrowth induced by a-lipoic acid. Biochim Biophys Acta 2011, 1813:827-838.

32. Wang Z, Wang J, Li J, Wang X, Yao Y, Zhang X, Cheng Y, Ding G, Liu L: MEK/ERKs signaling is essential for lithium-induced neurite outgrowth in N2a cells. Int J Dev Neurosci 2011, 29:415-222.

33. Wasilewska-sampaio AP, Silveira MS, Holub O, Goecking R, Gomes CA, Neto VM, Linden R, Ferreira T, Felice FGD: Neuritogenesis and neuronal differentiation promoted by 2,4-dinitrophenol, a novel antiamyloidogenic compound. FASEB J 2005, 19:1627-1636.

34. Radio NM, Mundy WR: Developmental neurotoxicity testing in vitro: models for assessing chemical effects on neurite outgrowth. Neurotoxicol 2008, 29(3):361-376.

35. Sofroniew MV, Howe CL, Mobley WC: Nerve growth factor signaling, neuroprotection, and neural repair. Annu Rev Neurosci 2001, 24:1217-1281.

36. Tsuji M, Inanami $\mathrm{O}$, Kuwabara M: Neuroprotective effect of a-phenyl-Ntert-butylnitrone in gerbil hippocampus is mediated by the mitogenactivated protein kinase pathway and heat shock proteins. Neurosci Lett 2000, 282:41-44.

37. Zhang W, Liu HT: MAPK signal pathways in the regulation of cell proliferation in mammalian cells. Cell Res 2002, 12(1):9-18.

38. Maria AS, Lopez A, Diaz MM, Alba J: Evaluation of the toxicity of Uncaria tomentosa by bioassays in vitro. J Ethnopharmacol 1997, 57:183-187.

39. Yang F, Lim GP, Begum AN, Ubeda OJ, Simmons MR, Ambegaokar SS, Chen PP, Kayed R, Glabe CG, Frautschy SA, Cole GM: Curcumin inhibits formation of amyloid b oligomers and fibrils, binds plaques, and reduces amyloid in vivo. J Biol Chem 2005, 280:5892-58901.

40. Sasidharan S, Jinxuan O, Latha LY, Amutha S: In vivo toxicity study of Ganoderma boninense. Afr J Pharm Pharmaco 2011, 5(16):1819-1823.

41. Smina TP, Mathew J, Janardhanan KK, Devasagayam TPA: Antioxidant activity and toxicity profile of total triterpenes isolated from Ganoderma lucidum (Fr.) P. Karst occurring in South India. Environ Toxicol Phar 2011, 32:438-446.

42. Chen SN, Nan FH, Chen S, Wu JF, Lu CL, Soni MG: Safety assessment of mushroom $\beta$-glucan: Subchronic toxicity in rodents and mutagenicity studies. Food Chem Toxicol 2011, 49:2890-2898.

43. Shien S, Hong N, Yee S, Pailoor J, Mui S: Evaluation of the sub-acute toxicity of the sclerotium of Lignosus rhinocerus (Cooke ), the tiger milk mushroom. J Ethnopharmacol 2011, 138:192-200.

44. Weyermann J, Lochmann D, Zimmer A: A practical note on the use of cytotoxicity assays. Int J Pharmaceut 2005, 288(2):369-376.

45. Fotakis $G$, Timbrell JA: In vitro cytotoxicity assays: Comparison of LDH, neutral red, MTT and protein assay in hepatoma cell lines following exposure to cadmium chloride. Toxicol Lett 2006, 160:171-177.

doi:10.1186/1472-6882-13-261

Cite this article as: Phan et al:: Neurite outgrowth stimulatory effects of culinary-medicinal mushrooms and their toxicity assessment using differentiating Neuro-2a and embryonic fibroblast BALB/3T3. BMC Complementary and Alternative Medicine 2013 13:261. 